\title{
Francis Fontan memorial 1929-2018
}

\author{
Thomas L. Spray, MD, and J. William Gaynor, MD
}

From the Division of Cardiothoracic Surgery, The Children's Hospital of Philadelphia, Philadelphia, Pa.

Received for publication April 19, 2018; accepted for publication April 19, 2018; available ahead of print June 12, 2018.

Address for reprints: Thomas L. Spray, MD, Children's Surgical Associate, Ltd, Department of Cardiothoracic

Surgery, 34th St and Civic Center Blvd, Philadelphia, PA 19104 (E-mail: spray @email.chop.edu).

J Thorac Cardiovasc Surg 2018;156:1164-5

$0022-5223 / \$ 36.00$

Copyright $(\subset) 2018$ by The American Association for Thoracic Surgery

https://doi.org/10.1016/j.jtcvs.2018.04.105

Francis Fontan was born in Nay, in the province of Bearn in France. His father, Victor, was a noted professional cyclist and achieved fame as the "King of Mountains" in the Tour de France.

At age 17 years, after the end of the war, he entered the Faculte des Medecins at the University of Bordeaux. He spent 6 years as a medical student in Bordeaux before service at the university's hospitals as an intern, 1 of only 13 of 100 students to gain an internship. In his third year of internship, he entered the department of cardiac surgery working under Georges Dubourg.

Extracorporeal circulation had been introduced to France in 1955 and Bordeaux in 1956, and the use of such circuits became the topic for Professor Fontan's doctoral thesis. By 1959, he had become Chef de Clinique of the Medical Department of Cardiology, and in 1960, he became the Chef de Clinique of the Surgical Department of Cardiac Diseases under Professor Dubourg. He was appointed Professor in 1963 and assumed the leadership of the surgical department of Cardiac Diseases at the University of Bordeaux.

Professor Fontan became interested in tricuspid atresia after caring for a young teenager who died while he was an intern in cardiac surgery. His mentor, Dr Dubourg, suggested he use this experience to examine the treatment options for tricuspid atresia, where Dr Fontan noted that in the absence of a functional right ventricle the only "correction" possible would be heart transplantation. Professor Fontan's research then evolved with the knowledge of the cavopulmonary shunt proposed by Glenn and Patino, ${ }^{2}$ and he considered that if the nonpulsatile superior caval flow could be adequate to supply the right lung, then perhaps the inferior vena caval flow could be similarly baffled. ${ }^{2}$ After extensive work in the surgical laboratory, he noted that closure of the tricuspid valve and bypassing the right ventricle was not successful in animals, and the experimental work was not published. He was then approached again about a young female adolescent with tricuspid atresia. Dr Fontan suggested that the operation that was unsuccessful in animals might be a possibility, and he proceeded to perform what is now well recognized as the Fontan procedure. He created an

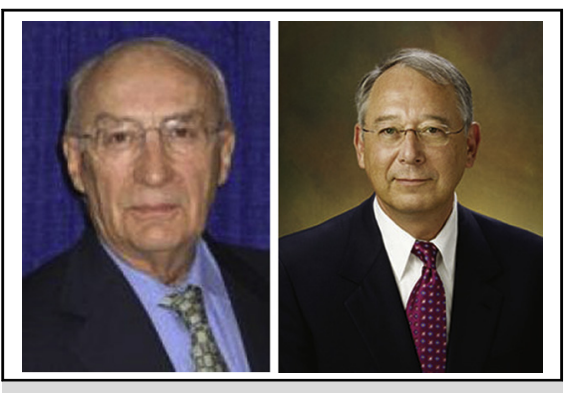

Dr Fontan (left) and Dr Spray (right).

Central Message

Francis Fontan, 1929-2018.

end-to-end anastomosis of the superior vena cava to the right pulmonary artery and then connected the right atrium directly to the remaining part of the bifurcation of the pulmonary arteries. The initial operation included a homograft valve at the orifice of the vena cava on the assumption that the upright posture in humans would cause inefficiency of blood flow from the lower body. The ability to use the homograft was related to the fact that since 1965 Professor Fontan had established the first homograft bank on the continent of Europe. The initial patient had a stormy postoperative course with pleural effusions, as well as renal failure, but recovered. Serial hemodialysis was necessary before the patient ultimately was discharged. As of 1999, this initial patient continued to do well after interim removal of the stenotic calcified aortic homograft. ${ }^{1}$

Professor Fontan did not report his initial experience, but in 1970 he was confronted by a second patient with tricuspid atresia and discordant atrioventricular connection at the age of 30 years who had received no previous operations. The procedure was similar to the initial operation, but the aortic homograft was placed between the right atrium and the pulmonary artery. This patient had a smoother postoperative course and eventually gave birth to a healthy child, but ultimately died of progressive mitral regurgitation. The experience with these 2 initial cases was published in a French journal in $1971 .^{3}$ A third patient underwent operation before the acceptance and publication of this article, and the 3 cases were then published in Thorax. ${ }^{4}$ The publication in English caught the notice of international congenital heart surgeons. Several modifications of the Fontan procedure were then devised, and Kreutzer and colleagues ${ }^{5}$ offered the alternative of using the patient's own pulmonary valve to achieve the aortopulmonary connection 
and subsequently a procedure with no valve in the circuit that has become the standard approach.

Professor Fontan had a strong relationship with Professor Gerard Brom in Leiden, and by 1983, 100 patients had undergone the Fontan procedure at the 2 institutions. ${ }^{6}$ Further developments of his operation ensued with publication of the "10 Commandments" for successful total cavopulmonary connection. An analysis of the results of the "perfect" Fontan operation was also undertaken with John Kirkland at the University of Alabama. ${ }^{7}$

Since the initial description of the Fontan cavopulmonary connection in 1971, countless patients have benefited from his surgical innovation and dedicated exploration of the boundaries for success in the procedure.

Although Professor Fontan is most known for his eponymous procedure, he was an excellent congenital heart surgeon achieving superb results in the range of complex cardiac repairs including the arterial switch procedure. Professor Fontan also performed the first cardiac transplantation in France.

Francis Fontan is also very well known throughout Europe and the world for the part he played in the establishment of the European Association of Cardiothoracic Surgery. Professor Fontan was instrumental in the creation of the Association and was its first president. The Francis Fontan Prize is now awarded annually to an applicant from Europe permitted to spend 1 year of training with the support of the Association. Professor Fontan and his wife Maryse had many hobbies, including golf and traveling. With his son, Edouard and colleagues, he has developed the Chateau l'Ermitage vineyard in Sauternes and is now producing wines that have received acclaim.

Professor Fontan was an extraordinarily kind and thoughtful individual who cared deeply about his patients and students and the advancement of the field of pediatric cardiothoracic surgery in Europe and the rest of the world. I (T.L.S.) personally consider Francis Fontan as a mentor, although I never spent any significant time training with him. When I was just out of my fellowship training as a junior attending at St Louis Children's Hospital at Washington University, I had the privilege of visiting Francis Fontan in Bordeaux. Although I was a very young and inexperienced surgeon with no fellowship training in congenital heart surgery, I spent several days in Bordeaux with Dr Fontan going over many cases of congenital heart disease where we discussed the surgical options and techniques for repair. This was a formative time in my career, and I have always been profoundly thankful for the time and effort he spent with me.

Francis Fontan was an extraordinary individual and a true pioneer in the field of congenital heart surgery, and his name will be long remembered.

\section{Conflict of Interest Statement}

Authors have nothing to disclose with regard to commercial support.

\section{References}

1. Anderson RH. The paediatric cardiology hall of fame. Francis Fontan. Cardiol Young. 1999;9:592-600.

2. Glenn WWL, Patino JF. Circulatory bypass of right heart: preliminary observation on direct delivery of vena caval blood into pulmonary arterial circulation. Azygos vein-pulmonary artery shunt. Yale J Biol Med. 1954;27:147-51.

3. Fontan F, Mounicot FB, Bauder E, Simonneau J, Gordo J, Gouffrant JM. "Correction" de l'atresie tricuspidienne. Rapport de deux cas "corriges" par l'utilisation d'une technique chirurgicale nouvelle. Ann Chir Thorac Cardiovasc. 1971;10: $39-47$.

4. Fontan F, Deville C, Quaegebeur J, Ottenkamp J, Sourdille N, Choussat A, et al. Surgical repair of tricuspid atresia. Thorax. 1971;26:240-8.

5. Kreutzer G, Galindez E, Bono H, DePalma C, Laura JP. An operation for the correction of tricuspid atresia. J Thorac Cardiovasc Surg. 1973;66:613-41.

6. Fontan F, Deville C, Quagebeur J, Ottenkamp J, Sourdille N, Choussat A, et al Repair of tricuspid atresia in 100 patients. J Thorac Cardiovasc Surg. 1983;85: 647-60.

7. Fontan F, Kirklin JW, Fernandez G, Costa F, Naftel DC, Tritto F, et al. Outcome after a "perfect" Fontan operation. Circulation. 1990;81:1520-36. 